THE POWER PROBLEM 



\section{THE POWER PROBLEM}

HOW AMERICAN MILITARY DOMINANCE MAKES US

LESS SAFE, LESS PROSPEROUS, AND LESS FREE

\section{CHRISTOPHER A. PREBLE}


A volume in the Series Cornell Studies in Security Affairs, edited by Robert J. Art, Robert Jervis, and Stephen M. Walt.

A list of titles in this series is available at www.cornellpress.cornell.edu.

\section{Copyright (C) 2009 by Cornell University}

All rights reserved. Except for brief quotations in a review, this book, or parts thereof, must not be reproduced in any form without permission in writing from the publisher. For information, address Cornell University Press, Sage House, 512 East State Street, Ithaca, New York 14850.

First published 2009 by Cornell University Press

\section{Printed in the United States of America}

Library of Congress Cataloging-in-Publication Data

Preble, Christopher A.

The power problem : how American military dominance makes us less safe, less prosperous, and less free / Christopher A. Preble.

p. cm. - (Cornell studies in security affairs)

Includes bibliographical references and index.

ISBN 978-0-8014-4765-5 (cloth : alk. paper)

1. United States-Military policy. 2. National security-United States.

3. Hegemony-United States. 4. Power (Social sciences) - United States.

I. Title. II. Series: Cornell studies in security affairs.

UA23.P6825 2009

$355^{\prime} .033073-\mathrm{dc} 22 \quad 2008052553$

Cornell University Press strives to use environmentally responsible suppliers and materials to the fullest extent possible in the publishing of its books.

Such materials include vegetable-based, low-VOC inks and acid-free papers that are recycled, totally chlorine-free, or partly composed of nonwood fibers. For further information, visit our website at www.cornellpress.cornell.edu.
Cloth printing
10
8
$\begin{array}{llllll}6 & 5 & 4 & 3 & 2 & 1\end{array}$ 
To Alex and Katelyn 

Madeleine Albright, our ambassador to the UN, asked me in frustration "What's the point of having this superb military that you're always talking about if we can't use it?" I thought I would have an aneurysm. American GIs were not toy soldiers to be moved around on some sort of global game board.

Colin Powell, My American fourney 
